\title{
Effects of varying levels of dietary palm oil in concentrate rations on dry matter intake, nutrients digestibility and nitrogen retention in Red Sokoto goats \\ Otaru*, S.M., Adamu, A.M., Ehoche, O.W. and Makun H.J. \\ National Animal Production Research Institute, Shika, Ahmadu Bello University, P.M.B. 1096, Zaria., Nigeria \\ *Corresponding Authour: S.M. Otaru. Telephone: +2348054524985. \\ E-mail address: otarusm@yahoo.com
}

\begin{abstract}
Twenty Red Sokoto bucks (average liveweight of $21.4 \pm 3.2 \mathrm{~kg}$ ) were used to evaluate the effects of varying levels of palm oil (PO) in concentraterations on nutrients digestibility and nitrogen retention. Five iso-nitrogenous concentrate supplements (CP $160 \mathrm{~g} / \mathrm{kg}$ concentrate) compounded with 0, 40, 80, 120 and $160 \mathrm{~g}$ palm oil/kg of concentrate, were used to supplement a basal diet of wooly finger grass (Digitaria smutsii, Stent) hay. The five supplements were designated as treatments 0-PO (control), 40-PO, 80-PO, 120-PO and 160$P O$. The bucks were each fed $536 \mathrm{~g} / \mathrm{d}$ of hay, and $343 \mathrm{~g} / \mathrm{d}$ of concentrate to give a ratio of 60:40 hay to concentrate. Results showed that inclusion of PO in the concentrate rations did not affect $(P>0.05)$ total dry matter intake of the goats but intake values declined slightly with further increase in levels of $P O$ beyond $40 \mathrm{~g} / \mathrm{kg}$ concentrate. No adverse effects on total tract digestibility of nutrients were observed. Nitrogen retention of the goats was positive and not affected $(P>0.05)$ by dietary levels of PO. It was concluded that inclusion of palm oil in the concentrate supplement beyond $40 \mathrm{~g} / \mathrm{kg}$ level for the Red Sokoto goats marginally depressed total dry matter intake, but had no adverse effects on the total tract digestibility of nutrients and nitrogen retention.
\end{abstract}

Keywords: Goats, Palm oil, Nutrient digestibility, Nitrogen retention

\section{Introduction}

Fat sources have played important roles in increasing energy density of diets and offer alternatives to feeding excessive amount of cereals, and thus prevent problems of ruminal acidosis, off-feed, lameness and low milk yield (Sudweeks et al., 1981; Harmon et al., 1985; Groehn et al., 1992). Other benefits of inclusion of fats in diets of ruminants were reported by Schroeder et al. (2004). However, one of the limitations of including fat in the diets of ruminants is the impairment of microbial activities in the rumen (Palmquist and Jenkins, 1980; Onetti et al., 2001; Franzolin, et al., 2010) by adsorbing onto bacteria (Jenkins, 1993) or defaunating the rumen microbes (Franzolin et al., 2010; Bhatt et al., 2011), especially, the cellulolytic protozoa - the Diplodiniinae (Franzolin et al., 2010). It has been reported that such impairment resulted in reduced cellulolysis and low fibre digestion in the rumen (Jenkins, 1993; Bhatt et al., 2011) which was associated with decreased concentration of ruminal acetic acid (Khorasani et al., 1992; Onetti et al., 2001). Polyunsaturated fats are more soluble and decrease fibre digestion than saturated fats (Palmquist and Jenkins, 1980; Sutton et al., 1983; Schauff and Clark, 1989; Coppock and Wilks, 1991; Brown-Crowder et al., 2001) but in terms of positive contribution to the environment, they are more effective in reducing methane emissions (Jouany, 1996; Machmüller et al., 1998). 
Effect of supplemental fats on rumen function and performance of animals depend on fat content of diet, fat sources, forage types and species of animals (Jenkins, 1993; Smith et al., 1993; Ben Salem et al., 1993; Onetti et al., 2002; Doreau and Ferlay, 1995; Franzolin et al., 2010). Smith et al. (1993) using tallow or cottonseed and Ben Salem et al. (1993) using rapeseed oil demonstrated that depression in digestibility of nutrients and performance by cows was reversed when corn silage-based diets were partially or wholly replaced with alfalfa hay-based diets. The type of forage and perhaps the amount of it fed are important in modulating the effect of supplemental fat in the rumen.

Palm oil produced from oil palm (Elaeis guineensis, Jacq) is abundantly available in Nigeria. It has equal levels of saturated and unsaturated fatty acids (Edem, 2002). In vitro study with some fats indicated that palm oil has minor effects on degradation of neutral detergent fibre (NDF) (Dohme et $a l ., 2000)$. Most in vivo studies with palm oil in respect of its effects on digestibility and utilization by ruminants involved the use of protected or rumen-inert palm oil (Bayourthe et al., 1994; Martín et al., 1999; Meyer et al., 2001; Onetti and Grummer, 2004; Appeddu, et al., 2004; Franzolin et al., 2010). Similar reports on the use of unprocessed or ruminally active palm oil in diets of ruminant animals are few (Solomon et al., 1992; Lough et al., 1993 and 1994), and more so in Nigeria. The Red Sokoto goats has uniformly dark red coat colour, and is the most numerous and widely distributed breed of goats in Nigeria. Other details concerning the Red Sokoto breed of goats had been reported (Otaru et al., 2011). There has been paucity of information on the effects of palm oil on digestibility of nutrients by indigenous goat breeds in
Nigeria. This study was carried out to evaluate the effects of varying dietary levels of palm oil in concentrate rations on dry matter intake, nutrients digestibility and nitrogen balance by Red Sokoto goats fed basal diet of Digitaria smutsii hay.

\section{Materials and methods}

\section{Location of study}

The study was carried out at the Experimental Unit of Small Ruminant Research Programme, National Animal Production Research Institute (NAPRI), Ahmadu Bello University, Shika - Zaria, Nigeria. Shika is located within the Northern Guinea Savannah Zone at Latitude $11^{\circ} 11^{\prime} \mathrm{N}$ and Longitude $7^{\circ} 34^{\prime} \mathrm{E}$, and is $640 \mathrm{~m}$ above the sea level.

\section{Metabolism trial}

Twenty Red Sokoto bucks with average liveweight of $21.4 \pm 3.2 \mathrm{~kg}$ were obtained from the flock of Red Sokoto goats of the Small Ruminant Research Programme, and used in a randomized complete block design for nutrient digestibility and nitrogen balance study. The animals were blocked according to weight and randomly allocated to five dietary treatment groups to give a total of four animals per treatment group.

The experimental diets consisted of Wooly finger grass (Digitaria smutsii, Stent) hay fed as basal diet. The supplements were concentrate mixtures compounded to contain palm oil (PO) at levels of $0,40,80$, 120 , or $160 \mathrm{~g} / \mathrm{kg}$ of concentrate designated as: 0 -PO (control), 40-PO, 80-PO, 120-PO or $160-\mathrm{PO}$, respectively. The concentrate mixtures were iso-nitrogenous (160 $\mathrm{g}$ crude protein $(\mathrm{CP}) / \mathrm{kg}$ concentrate dry matter (DM)) as shown in Table 1. The source of palm oil and the procedure for mixing of the concentrate supplements were as described by Otaru et al. (2011). 
The animals were de-wormed one week before the commencement of the study. They were also dipped in acaricide (Steladone $^{\circledR}$ 300EC) solution to control ecto-parasites. On the first day of the study, they were weighed and placed in individual metabolism crates designed for separate collection of total faeces and urine, the latter flowing down a gradient to be collected into 5-litre capacity plastic jericans which protects the urine against draught. The bucks were individually fed $536 \mathrm{~g} / \mathrm{d}$ of hay, and $343 \mathrm{~g} / \mathrm{d}$ of concentrate to give a ratio of 60:40 hay to concentrate. The procedure and duration of feeding the diets each day were as described by Otaru et al. (2011) in an earlier feeding trial with lactating Red Sokoto goats. After 14-day adjustment period, measurements of feed offered and remnants, total faeces and urine voided, as well as amounts of water consumed were taken for a period of seven consecutive days. For each animal, total urine output was collected into plastic container containing $20 \mathrm{ml}$ of $0.2 \mathrm{~N} \mathrm{HCl}$ to prevent loss of nitrogen (ILCA, 1993). Total faecal output from each animal was also collected and weighed fresh. Ten percent of each day's collection of urine and faeces was bulked at the end of the trial, and the urine kept in refrigerator until required for nitrogen analysis. The faecal samples were dried in the oven for $48 \mathrm{~h}$ at $70^{\circ} \mathrm{C}$, milled and stored in polythene bags kept inside tins until required for proximate analyses. Sub samples of feed offered and refused were also taken daily, bulked, milled and stored for proximate analysis. Final weights of the animals were taken at the end of the experiment but not shown in the Tables.

\section{Chemical analysis}

Samples of the diets and faeces were dried, ground through $1 \mathrm{~mm}$ sieve and further dried at $105^{\circ} \mathrm{C}$ for one hour to determine the residual dry matter of samples (AOAC, 1980). The nitrogen $(\mathrm{N})$ in the urine, diets and faeces were determined according to Kjeldahl procedure (AOAC, 1980). The crude protein $(\mathrm{CP})$ content was obtained by multiplying $\mathrm{N}$ by a factor of 6.25 . The Neutral detergent fibre (NDF) and Acid detergent fibre (ADF) contents of the diets, feed ingredients and faecal samples were determined according to the procedure of Goering and Van Soest (1970). The AOAC (1980) procedures were followed to determine the ether extract (EE) and ash contents of the diets and faecal samples. The gross energy content of the diets was determined using ballistic bomb calorimeter (Gallenkamp).

\section{Calculations and Statistical analyses}

Non-structural carbohydrate (NSC) concentrations of the diets was estimated by equation: $\mathrm{OM}-(\mathrm{CP} \%+\mathrm{NDF} \%+$ ether extract\%) (Arieli et al., 2005).

Data on daily intakes of nutrients, DM and water whose values were correlated because of repeated measures, were subjected to analysis of variance for repeated measure analysis using PROC MIXED procedure of SAS (SAS, 2000, version 8.1, SAS Institute Inc., Carry NC). The statistical model used is: $Y_{\mathrm{ijk}}=\mu+t_{\mathrm{i}}+\mathrm{b}_{\mathrm{j}}$ $+p_{k}+t_{i k}+e_{i j k}$, where, $Y_{i j k}$ is the response of animal $\mathrm{j}$ in treatment $\mathrm{i}$ at time $\mathrm{k}, \mu$ is the overall mean, $t_{i}$ is a fixed effect of the ith treatment $(i=1,2,3,4,5), b_{j}$ is the random effect of the $j$ th animal $(j=1,2,3,4)$ nested within the ith treatment, $p_{k}$ is the fixed effect of kth time $(p=1,2, \ldots \ldots . .7), \mathrm{tp}_{\mathrm{ik}}$ is the interaction between the ith treatment and the kth time, $\mathrm{e}_{\mathrm{ijk}}$ is the random error. For each variable analyzed under this model, animal as a subject nested within treatment was subjected to four covariance structures: Compound symmetry (CS), unstructured 
Effects of varying levels of dietary palm oil in concentrate rations on nutrients digestibility in Red Sokoto goats

Table 1: Composition of hay and concentrate mixtures containing different levels of palm oil (PO)

Levels of PO in concentrate $(\mathrm{g} / \mathrm{kg})$

\begin{tabular}{|c|c|c|c|c|c|}
\hline \multirow[b]{2}{*}{ Ingredient composition, $\mathrm{g} / \mathrm{kg}$ (as fed) } & \\
\hline & $0-P O$ & 40-PO & $80-P O$ & $\begin{array}{r}120- \\
P O \\
\end{array}$ & $\begin{array}{r}160- \\
P O \\
\end{array}$ \\
\hline Maize & 378.7 & 338.7 & 298.7 & 258.7 & 218.7 \\
\hline Maize offal & 189.4 & 189.4 & 189.4 & 189.4 & 189.4 \\
\hline Palm oil & 0.0 & 40.0 & 80.0 & 120.0 & 160.0 \\
\hline Cotton seed cake & 391.9 & 390.4 & 389.0 & 387.5 & 386.1 \\
\hline Urea & 0.0 & 1.5 & 2.9 & 4.4 & 5.8 \\
\hline Bone meal & 25.0 & 25.0 & 25.0 & 25.0 & 25.0 \\
\hline Common salt & 15.0 & 15.0 & 15.0 & 15.0 & 15.0 \\
\hline
\end{tabular}

\begin{tabular}{lrrrrrr} 
Chemical composition, g/kg DM & D. smutsii hay \\
\hline OM & 901.1 & 900.9 & 893.0 & 900.6 & 905.1 & 907.7 \\
CP & 60.00 & 161.9 & 166.9 & 166.5 & 174.2 & 175.0 \\
EE & 61.4 & 117.5 & 127.6 & 169.7 & 219.4 & 246.6 \\
NDF & 696.7 & 397.7 & 395.9 & 379.8 & 371.0 & 358.7 \\
ADF & 451.0 & 245.7 & 230.3 & 163.4 & 209.4 & 274.2 \\
Ash & 71.6 & 66.3 & 70.3 & 68.2 & 73.3 & 70.3 \\
Non-structural carbohydrate (NSC) & 83.0 & 224.1 & 202.6 & 184.6 & 140.5 & 127.4 \\
Gross energy (GE, MJ/kg DM) & 17.66 & 16.05 & 16.08 & 17.97 & 19.56 & 20.09 \\
\hline
\end{tabular}


(UN), autoregressive order [ AR(1)] and heterogeneous autoregressive [ARH (1)]. The covariance structure that yielded the smallest Akaike's Information Criterion (AIC) was used. UN was used for total DM intake, total OM intake, concentrate DM intake, and intakes of $\mathrm{CP}, \mathrm{NDF}, \mathrm{ADF}, \mathrm{NSC}$ and water. Autoregressive order [AR(1)] was used for the intakes of EE and hay DM. When effect of treatment, time or treatment $x$ time interaction was significant, Bonferroni multiple comparisons test was used to determine differences among LeastSquares Means. Orthogonal polynomial contrast was run in accordance with the procedures of SAS (2000) to establish the linear, quadratic and cubic relationships between the variables and dietary palm oil levels.

Digestibility coefficients of nutrients, urine and faecal outputs, nitrogen intake and retention were analyzed by ANOVA using the General Linear Model (GLM) procedures of the statistical Analysis Systems (SAS, 2000) in accordance with the following statistical model: $Y_{i j}=\mu+b_{j}+$ $t_{i}+e_{i j}$, where $Y_{i j}$ is the response of animal $j$ in treatment $i, \mu$ is the overall mean, $b_{j}$ is a fixed effect of the jth block $(j=1,2,3,4)$ within the ith treatment, $t_{i}$ is a fixed effect of the ith treatment $(\mathrm{i}=1,2,3,4,5), \mathrm{e}_{\mathrm{ij}}$ is the random error. Least-Squares Means were separated using the PDIFF OPTION of SAS (SAS, 2000).

Differences between treatment means were declared significant at $\mathrm{P}<0.05$. Tendency to differences between treatments were declared at $\mathrm{P}>0.05$ and $<0.1$.

\section{Results}

Nutrient intake

Table 2 shows the intake and apparent digestibility coefficients of nutrients of the goats. The total dry matter intake (DMI) was not significantly different $(\mathrm{P}>0.05)$ between treatments, even though total DMI peaked at 40-PO level and declined thereafter. According to the observed intakes of hay and concentrates, final level of PO in the total diet was $0,19,40,64$ or 78 $\mathrm{g} / \mathrm{kg}$ dry matter, for $0-\mathrm{PO}, 40-\mathrm{PO}, 80-\mathrm{PO}$, $120-\mathrm{PO}$ or $160-\mathrm{PO}$ treatments, respectively. The ratio of hay intake to that of concentrate was on the average 50:50 across diets. Similar to the total DMI, no significant $(\mathrm{P}>$ $0.05)$ differences were observed between the treatments for the intakes of $\mathrm{OM}, \mathrm{CP}$, NDF and ADF. The intake of EE was significantly $(\mathrm{P}<0.05)$ affected by treatment. The highest intake of $\mathrm{EE}$ was recorded by goats fed $120-\mathrm{PO}$ concentrate which consumed $67 \%(\mathrm{P}<0.01)$ and $47 \%$ $(\mathrm{P}<0.05)$ more $\mathrm{EE}$ than goats which correspondingly received $0-\mathrm{PO}$ or $40-\mathrm{PO}$ concentrate. Furthermore, the intake of $\mathrm{EE}$ by goats receiving 160-PO concentrate was significantly $(\mathrm{P}<0.05)$ higher than the intake of those fed 40-PO concentrate but comparable to that of the group offered 80PO concentrate. The differences in the intake of NSC between goats receiving 0$\mathrm{PO}$ or 40-PO concentrate and their counterparts fed160-PO concentrate tended to be significant $(\mathrm{P}=0.07)$. The EE intake showed a linear $(\mathrm{P}<0.01)$ increase to levels of PO in the concentrate, whereas NSC intake exhibited a linear $(\mathrm{P}<0.05)$ decrease.

\section{Digestibility and nitrogen balance}

The digestibility coefficient values for most of the nutrients were generally less than 600 $\mathrm{g} / \mathrm{kg}$ except those for EE and NSC, which were between 610 and $740 \mathrm{~g} / \mathrm{kg}$. The treatment had no effect $(\mathrm{P}>0.05)$ on the digestibility of all the nutrients, however, the differences between $0-\mathrm{PO}$ or 40-PO and $160-\mathrm{PO}$ for crude protein digestibility, and between $0-\mathrm{PO}$ and $120-\mathrm{PO}$ or $160-\mathrm{PO}$ for ether extract digestibility tended to be 
Effects of varying levels of dietary palm oil in concentrate rations on nutrients digestibility in Red Sokoto goats

Table 2: Intake and apparent digestibility coefficients of nutrients in Red Sokoto goats (bucks) fed concentrate diets containing varying levels of palm oil (PO)

\begin{tabular}{|c|c|c|c|c|c|c|c|c|c|}
\hline \multirow[b]{2}{*}{ Parameter } & \multirow[b]{2}{*}{$0-P O$} & \multirow[b]{2}{*}{$40-P O$} & \multirow[b]{2}{*}{$80-P O$} & \multirow[b]{2}{*}{$120-P O$} & \multirow[b]{2}{*}{$160-P O$} & \multirow[b]{2}{*}{ SEM } & \multicolumn{3}{|c|}{ PO level effect, $\mathrm{P}<$} \\
\hline & & & & & & & $\mathrm{L}$ & $\mathrm{Q}$ & $\mathrm{C}$ \\
\hline \multicolumn{10}{|c|}{ Dry Matter intake (g/d) } \\
\hline Hay & 409.03 & 444.20 & 379.12 & 382.06 & 364.49 & 65.49 & $\mathrm{NS}^{1}$ & NS & NS \\
\hline Concentrate & 382.87 & 406.07 & 384.06 & 429.77 & 342.71 & 60.94 & NS & NS & NS \\
\hline Total & 791.89 & 850.26 & 763.18 & 811.83 & 707.20 & 124.23 & NS & NS & NS \\
\hline \multicolumn{10}{|c|}{ Nutrient intake $(\mathrm{g} / \mathrm{d})$} \\
\hline $\mathrm{OM}$ & 735.54 & 787.93 & 708.24 & 751.51 & 655.74 & 115.21 & NS & NS & NS \\
\hline $\mathrm{CP}$ & 89.32 & 97.75 & 89.39 & 100.09 & 83.81 & 14.35 & NS & NS & NS \\
\hline $\mathrm{EE}$ & $72.33^{\mathrm{c}}$ & $81.83^{\mathrm{bc}}$ & $91.20^{\mathrm{abc}}$ & $120.49^{\mathrm{a}}$ & $109.42^{\mathrm{ab}}$ & 11.62 & 0.01 & NS & NS \\
\hline NDF & 450.40 & 485.05 & 422.11 & 436.61 & 386.76 & 70.15 & NS & NS & NS \\
\hline ADF & 286.91 & 303.03 & 240.56 & 269.12 & 265.10 & 44.23 & NS & NS & NS \\
\hline NSC & 123.61 & 123.31 & 105.53 & 94.32 & 75.75 & 17.10 & 0.02 & NS & NS \\
\hline \multicolumn{10}{|c|}{ Digestibility ( $\mathrm{g} / \mathrm{kg}$ ) } \\
\hline DM & 506.5 & 523.1 & 558.1 & 554.0 & 554.0 & 47.0 & $\mathrm{NS}^{1}$ & NS & NS \\
\hline $\mathrm{OM}$ & 543.9 & 554.0 & 584.0 & 584.5 & 578.3 & 45.2 & NS & NS & NS \\
\hline $\mathrm{CP}$ & 335.5 & 334.1 & 442.7 & 434.8 & 473.5 & 52.4 & 0.04 & NS & NS \\
\hline $\mathrm{EE}$ & 611.7 & 641.1 & 703.5 & 738.0 & 733.3 & 45.7 & 0.04 & NS & NS \\
\hline NDF & 542.2 & 516.4 & 561.7 & 542.2 & 543.2 & 58.7 & NS & NS & NS \\
\hline ADF & 425.4 & 378.0 & 403.2 & 380.5 & 499.2 & 92.2 & NS & NS & NS \\
\hline NSC & 620.0 & 671.3 & 664.0 & 709.4 & 620.3 & 50.7 & NS & NS & NS \\
\hline
\end{tabular}

${ }^{1} \mathrm{NS}=\mathrm{P}>0.05$.

$\mathrm{NS}=\mathrm{P}>0.05$

$\mathrm{L}, \mathrm{Q}$, and C = Linear, quadratic and cubic response to palm oil level

Table 3: Nitrogen intake and retention in Red Sokoto bucks fed concentrate diets containing varying levels of palm oil (PO)

\begin{tabular}{|c|c|c|c|c|c|c|c|c|c|}
\hline \multirow[b]{2}{*}{ Parameter } & \multirow[b]{2}{*}{$0-P O$} & \multirow[b]{2}{*}{$40-P O$} & \multirow[b]{2}{*}{$80-P O$} & \multirow[b]{2}{*}{$120-P O$} & \multirow[b]{2}{*}{$160-P O$} & \multirow[b]{2}{*}{ SEM } & \multicolumn{3}{|c|}{ PO level effect, $\mathrm{P}<$} \\
\hline & & & & & & & $\mathrm{L}$ & $\mathrm{Q}$ & $\mathrm{C}$ \\
\hline Total nitrogen intake (g) & 13.21 & 14.47 & 13.59 & 15.00 & 12.44 & 2.22 & NS & NS & NS \\
\hline Water intake (1/d) & 2.29 & 2.58 & 2.07 & 2.32 & 1.80 & 0.36 & NS & NS & NS \\
\hline Total urine output $(\mathrm{ml})$ & 471.57 & 594.93 & 327.00 & 462.89 & 243.82 & 146.85 & $\mathrm{NS}^{1}$ & NS & NS \\
\hline Total faecal output (g) & 412.50 & 424.10 & 319.29 & 368.93 & 330.54 & 85.41 & $\mathrm{NS}$ & NS & NS \\
\hline Faecal nitrogen output (g) & 9.02 & 9.71 & 7.60 & 8.42 & 6.67 & 1.89 & NS & NS & NS \\
\hline Urine nitrogen output (g) & 3.18 & 3.42 & 2.13 & 3.49 & 2.29 & 0.77 & NS & NS & NS \\
\hline Total nitrogen output (g) & 12.21 & 13.13 & 9.73 & 11.91 & 8.96 & 2.50 & NS & NS & NS \\
\hline Nitrogen balance (g) & 1.00 & 1.33 & 3.86 & 3.10 & 3.49 & 1.33 & NS & NS & NS \\
\hline Nitrogen retention $(\mathrm{g} / \mathrm{kg} \mathrm{NI})$ & 98.6 & 99.2 & 287.2 & 184.1 & 298.0 & 78.8 & NS & NS & NS \\
\hline
\end{tabular}

$\mathrm{L}, \mathrm{Q}$, and $\mathrm{C}=$ Linear, quadratic and cubic response to palm oil level.

$\mathrm{NI}=$ Nitrogen intake 
significant $(\mathrm{P}=0.08)$. Digestibility of $\mathrm{CP}$ and $\mathrm{EE}$ both showed significant $(\mathrm{P}<0.05)$ linear increase to increasing levels of palm oil in the concentrate.

The mean daily nitrogen intake and retention are presented in Table 3. The effect of levels of PO in the concentrate on water intake, nitrogen intake and retention, urine and faecal output was not significant $(P>0.05)$, but the mean values for per cent nitrogen retention were positive for all treatments, and tended to increase linearly $(\mathrm{P}=0.07)$ to dietary level of palm oil.

\section{Discussion}

Nutrient intake

Increasing the levels of dietary palm oil did not markedly affect the DMI of goats. This agrees with similar findings on cows (Schauff and Clark, 1989) and goats (Sanz Sampelayo et al., 2002; Mele et al., 2008) fed diets containing supplemental fats. From our results, it would appear that while there were no significant differences between treatments, DMI peaked at 40-PO and declined by as much as $17 \%$ with further increase in the level of dietary PO. The lack of significant effect of palm oil on DMI as observed in this study contradicts previous reports where cows receiving supplemental fat had significantly lower DMI than those fed diets without fat supplement (Onetti et al., 2001 and 2002). Findings from a recent study on lambs fed Ailanthus excelsa leaves supplemented with concentrate mixture containing 0,25 , 50 and $75 \mathrm{~g}$ coconut oil $/ \mathrm{kg}$ (Bhatt et al., 2011) showed that DMI was significantly affected by coconut oil supplementation compared with the control group either in the pre or post weaning period. Dry matter intake (DMI) increased linearly during the pre weaning phase and decrease linearly during the post weaning phase with further increases in levels of dietary coconut oil.
The difference between the observed DMI in this study and that of Onetti et al. (2001) and (2002) may be attributed to differences in the nature of forage and supplemental fat fed, and the form in which the diets were fed. The author used corn silage or mixture of corn silage and alfalfa silage, and tallow or choice white grease all of which were fed as total mixed ration. Digitaria smutsii hay was used in this study, and was offered ad libitum. According to Jenkins (1993) fats that normally inhibit fermentation and digestion often cause less inhibition when hay content of the basal diet is high. The sheep used by Bhatt et al. (2011) were young lamb and might not have gotten well developed rumen to cope with digestion of diets containing supplemental fat, thus underscoring differences between our study (where mature bucks were used) and theirs in terms of intake response.

The positive linear relationship between EE intake and the levels of PO in the concentrate shows that the goats offered higher amounts of dietary PO significantly ingested more EE than those fed lower levels of dietary PO. The observed marked treatment effect in this study is consistent with earlier reports which showed that inclusion of supplemental fat in the diets significantly increased fat intake in cows (Storry et al., 1967) and ewes (Appeddu et al., 2004). Although intakes of OM, CP, NSC and fibre components were unaffected significantly, successive increase in dietary level of PO elicited linear decrease in that of NSC. Intake of NSC decreased probably because PO replaced maize grain which was the main source of NSC in the diets.

\section{Digestibility and nitrogen balance}

The digestibility of nutrients in goats receiving palm oil containing diets were not different from those of goats fed the control diet, thus agreeing with the findings of 
Schauff and Clark (1989) on cattle receiving fat supplement, while conflicting with those of similar works on sheep (Machmüller et al., 2000; Appeddu et al., 2004; Bhatt et al., 2011) where supplemental fat markedly reduced digestibility of nutrients. One of the limitations of fat supplement is their effect on ruminal fiber digestion by exerting negative effects on cellulolytic and methanogenic microorganisms in the rumen through the direct action of fatty acids on cellular membrane of the microbes, or/and indirect effect of reduction in the ruminal availability of cations such as calcium and magnesium ( Schroeder et al., 2004). Fibre digestion was not significantly affected in the present study probably because of the nature of fat source used. Palm oil has equal level of saturated and unsaturated fatty acids (Edem, 2002). The higher the level of unsaturation in fats the more the reduction in fibre digestibility (Brown-Crowder et al., 2001).

The linear increase in ether extract digestibility to dietary levels of palm oil supports consistent increase in $\mathrm{EE}$ digestibility when calcium salts of fatty acids (Bayourthe et al., 1994) or coconut oil (Bhatt et al., 2011) in the diets of sheep was successively increased.

Although treatment differences were not significant for all nitrogen balance parameters measured, the mean values for per cent nitrogen retention were positive and showed a tendency towards a linear increase with increase in dietary level of PO. This is consistent with earlier observation in sheep fed supplemental fat (Bayourthe et al., 1994) but contradicts reports on sheep where supplemental fat (coconut oil) linearly decreased nitrogen retention (Bhatt et al., 2011). The difference between the present result and those of
Bhatt et al. (2011) in terms of response of nitrogen retention to supplemental fat could be accounted for by the differences in the age of the animals used. We used fairly mature goats as opposed to young lambs used by Bhatt et al. (2011).

Based on the virtual linearity of per cent nitrogen retention to increase in dietary levels of PO, it is tempting to infer that intake of more energy enhanced more nitrogen retention (Lykos and Varga, 1997; Huhtanen et al., 1995) because glucogenic amino acids or protein are spared and not used for gluconeogenesis (Lemosquet et al., 2004) due to utilization of ruminal propionate subsequent to enhancement of its production by ingestion of fat (Johnson and Johnson, 1995). But this was not likely the case because a critical look at Table 3 indicates that the level of nitrogen retention was more associated with or influenced by the amount of urine and faecal output and their derivatives (that is, urine and faecal nitrogen output). Animals with large quantities of urine and/or faeces had the lowest nitrogen retention. Earlier, in a similar study, Bayourthe et al. (1993) attributed the nitrogen and energy retention they obtained in sheep to the decrease in fecal and/or urinary excretion(s). The quantities of urine and faeces voided might have had a link with the amount of water consumed which in turn was influenced by DMI.

\section{Conclusion}

It was concluded that inclusion of palm oil in the concentrate supplement up to $40 \mathrm{~g} / \mathrm{kg}$ level for the Red Sokoto goat (bucks) elicited the highest DMI. Further increase in level of palm oil beyond $40 \mathrm{~g} / \mathrm{kg}$ of concentrate caused marginal decline in DMI and had no adverse effects on the total tract digestibility of nutrients and nitrogen retention. 


\section{Acknowledgements}

The authours are grateful to the Staff of Small Ruminant Research Programme and Central Laboratory Unit of the National Animal Production Research Institute (NAPRI), Ahmadu Bello University, ShikaZaria for their assistance and moral support during the course of the experiment. We also appreciate the provision of funds for this research by NAPRI, and the permission of the Director of the Institute to publish this work.

\section{References}

A.O.A.C., 1980. Association of Official Analytical Chemists. Official Methods of Analysis. (13 ${ }^{\text {th }}$ Ed.). Washington, D.C.

Arieli, A., Sasson-Rath, R., Zamwel, S. and Mabjeesh, S.J., 2005. Effect of dietary protein and rumen degradable organic matter on milk production and efficiency in heat-stressed goats. Livest. Prod. Sci. 96, 215-223.

Appeddu, L.A., Ely, D.G., Aaron, D.K., Deweese, W.P. and Fink, E., 2004. Effects of supplementing with calcium salts of palm oil fatty acids or hydrogenated tallow on ewe milk production and twin lamb growth. $J$. Anim. Sci. 82, 2780-2789.

Ben Salem, H., Krzeminski, R., Ferlay, A. and Doreau, M., 1993. Effect of lipid supply on in vivo digestion in cows: comparison of hay and corn silage diet. Can. J. Anim. Sci. 73, 547 - 557

Bhatt, R.S., Soren, N.M., Tripathi, M.K. and Karim, S.A., 2011. Effects of different levels of coconut oil supplementation on performance, digestibility, rumen fermentation and carcass traits of Malpura lambs. Anim. Feed Sci. Technol. 164, 29-37.

Bayourthe, C., Vernay, M. and Moncoulon, R., 1994. Effect of calcium salts of fatty acids on rumen function and the digestibility of rations by sheep. J. Sci. Food Agric. 64, $341-$ 347.

Bayourthe, C., Moncoulon, R. and Vernay, M., 1993. Effect of proteinprotected fat on ruminal and total nutrient digestibility of sheep diets. $J$. Anim. Sci. 71, 1026-1031.

Brown-Crowder, I.E., Hart, S.P., Cameron, M., Sahlu, T. and Goetsch, A.L., 2001. Effects of dietary tallow level on performance of Alpine does in early lactation. Small Rumin. Res. 39, 233-241.

Coppock, C.E. and Wilks, D.L., 1991. Supplemental fat in high-energy rations for lactating cows: effect on intake, digestion, milk yiled, and composition. J. Anim. Sci. 69, $3826-$ 3837.

D oh m e, F., Ma ch mülle r, A., Wasserfallen, A. and Kreuzer, M., 2000. Comparative efficiency of various fats rich in medium-chain fatty acids to suppress ruminal methanogenesis as measured with RUSITEC. Can. J. Anim. Sci. 80, 473 -482 .

Doreau, M. and Ferlay, A., 1995. Effect of dietary lipids on nitrogen metabolism in the rumen: a review. Livest. Prod. Sci. 43, 97-110.

Edem, D.O., 2002. Palm oil: Biochemical, physiological, nutritional, hematological and toxicological aspects: A review. Plant Foods Hum. Nutr. 57 (3-4), 319-341.

Franzolin, R., Garcia, V.P., Soares,W.V.B. and Costa, F,A.A., 2010. Influence of palm fatty acid distillate on rumen degradability and protozoa in buffaloes. Italian J. Anim. Sc. 9: e75.

Goering, H.K and Van Soest, P.J., 1970. 
Effects of varying levels of dietary palm oil in concentrate rations on nutrients digestibility in Red Sokoto goats

Forage fibre analysis (Apparatus, reagents, procedures and some applications). Agricultural Handbook No. 379. Agricultural Research Services, U.S.A. Department of Agriculture, Washington, D.C.

Groehn, J.A., Kaneene, J.B. and Foster, D., 1992. Risk factors associated with lameness in lactating dairy cattle in Michigan. Preventive Vet. Med. 14, 77 -85 .

Harmon, D.L., Britton, R.A., Prior, R.L. and Stock, R.A., 1985. Net portal absorptrion of lactate and volatile fatty acids in steers experiencing glucoseinduced acidosis or fed a $70 \%$ concentrate diet ad libitum. J. Anim. Sci. 60, 560- 569 .

Huhtanen, P., Jaakkola, S. and Saarisalo, E., 1995. The effects of concentrate energy source on milk production of dairy cows given a grass silage-based diet. Anim. Sci. 60, 31-40.

ILCA (International Livestock Centre for Africa), 1993. Feed evaluation. ILCA Manual 5. Osuji, P.O., Nsahlai, I.V. and Khalili, H. (Eds.). Addis Ababa, Ethiopia. 40pp.

Jenkins, T.C., 1993. Lipid metabolism in the rumen. J. Dairy Sci. 76, 3851 3863.

Johnson, K.A. and Johnson, D.E., 1995. Methane emissions from cattle. $J$. Anim. Sci. 73, 2483-2492.

Jouany, J.P., 1996. Effect of rumen protozoa on nitrogen utilization by ruminants. J. Nutr. 126, 1335S $1346 \mathrm{~S}$

Khorasani, G.R., de Boer, G., Robinson, P.H. and Kennelly, J.J., 1992. Effect of canola fat on ruminal and total tract digestion, plasma hormones, and metabolites in lactating dairy cows. $J$. Dairy Sci. 75, 492-501.

Lemosquet, S., Rigout, S., Bach, A.,
Rulquin, H. and Blum, J.W., 2004. Glucose metabolism in lactating cows in response to isoenergetic infusions of propionic acid or duodenal glucose. $J$. Dairy Sci. 87, 1767-1777.

Lough, D.S., Solomon, M.B., Rumsey, T.S., Kahl, S. and Slyter, L.L., 1993. Effects of high-forage diets with added palm oil on performance, plasma lipids, and carcass characteristics of ram and ewe lambs. J. Anim. Sci. 71, $1171-1176$.

Lough, D.S., Solomon, M.B., Rumsey, T.S., Kahl, S. and Slyter, L.L., 1994. The effects of high forage with added palm oil on performance, plasma lipids, and carcass characteristics of ram lambs with initially high or low plasma cholesterol. J. Anim. Sci. 72, $330-336$.

Lykos, T. and Varga, G.A., 1997. Varying degradation rate of total nonstructural carbohydrates: Effects on nutrient uptake and utilization by the mammary gland in high producing Holstein cows. J. Dairy Sci. 80, 3356 - 3367.

Machmüller, A., Ossowski, D.A. and Kreuzer, M., 2000. Comparative evaluation of the effects of coconut oil, oilseeds and crystalline fat on methane release, digestion and energy balance in lambs. Anim. Feed Sci. Technol. 85, $41-60$.

Machmüller, A., Ossowski, D.A., Wanner, M. and Kreuzer, M., 1998. Potential of various fatty feeds to reduce methane release from rumen fermentation in vitro (Rusitec). Anim. Feed Sci. Technol. 85, 41-60.

Martín, L., Rodríguez, P., Rota, A., Rojas, A., Pascual, M.R., Patón, D. and Tovar, J., 1999. Effect of Protected fat supplementation to lactating goats on growth and fatty acid composition of perirenal fat in goat 
kids. Anim. Sci. 68, 195-200.

Mele, M., Serra, A., Buccioni, A., Conte, G., Pollicardo, A. and Secchiari, P., 2008. Effect of soybean oil supplementation on milk fatty acid composition from Saanen gaots fed diets with different forage:concentrate ratios. Ital. J. Anim. Sci. 7, 297-311.

Meyer, U., Daenicke, R. and Gadeken, D., 2001. Studies on the use of Casoaps of fatty acids in feeds for dairy cows. Zuchtungskunde, 73, 139 (Abstract).

Onetti, S.G. and Grummer, R. R., 2004. Response of lactating cows to three supplemental fat sources as affected by forage in diet and stage of lactation: a meta-analysis of literature. Anim. Feed Sci. Technol. 115, 65-82.

Onetti, S.G., Shaver, R.D., McGuire, M.A. and Grummer, R.R., 2001. Effect of type and level of dietary fat on rumen fermentation and performance of dairy cows fed corn silage-based diets. J. Dairy Sci. 84, 2751 - 2759.

Onetti, S.G., Shaver, R.D., McGuire, M.A., Palmquist, D.L. and Grummer, R.R., 2002. Effects of supplemental tallow on performance of dairy cows fed diets with different corn silage: Alfalfa silage ratios. $J$. Dairy Sci. 85, 632 - 641.

Otaru, S.M., Adamu, A.M., Ehoche, O.W. and Makun, H.J., 2011. Effects of varying the level of palm oil on feed intake, milk yield and composition and postpartum weight changes of Red Sokoto goats. Small Rumin. Res. 96, 25-35.

Palmquist, D.L., 1984. Use of fats in diets for lactating dairy cows. In: Wiseman. J. (Ed.). Fats in Animal Nutrition. Butterworths. London, pp 357-381.

Palmquist, D.L. and Jenkins, T.C., 1980. Fat in lactation rations: Review. $J$.
Dairy Sci. 63, 1- 14.

Sanz Sampelayo, M.R., Pérez, L., Martín Alonso, J.J., Gil Extremera, F. and Boza, J., 2002. Effects of concentrates with different contents of protected fat rich in PUFAs on the performance of lactating Granadina goats 1. Feed intake, nutrient digestibility, $\mathrm{N}$ and energy utilization for milk production. Small Rumin. Res. 43, 133-139.

SAS, 2000. Statistical Analysis Systems Institute. SAS User's Guide. Statistics, Version 8.1 Edition. SAS Inst., Inc., Cary, NC.

Schauff, D.J. and Clark, J.H., 1989. Effects of prilled fatty acids and calcium salts of fatty acids on rumen fermentation, nutrient digestibility, milk production and milk composition. J. Dairy Sci. 72, 917-927.

Schroeder, G.F., Gagliostro, G.A., Bargo, F., Delahoy, J.E. and Muller, L.D., 2004. Effects of fat supplementation on milk production and composition by dairy cows on pasture: a review. Livest. Prod. Sci. 86, 1- 18.

Smith, W.A., Harris, Jr. B., Van Horn, H.H. and Wilcox, C.J., 1993. Effect of forage type on production of dairy cows supplemented with whole cottonseed, tallow, and yeast. J. Dairy Sci. 76, 205-215.

Solomon, M.B., Lynch, G.P. and Lough, D.S., 1992. Influence of dietary palm oil supplementation on serum lipids metabolites, carcass characteristics, and lipid composition of carcass tissues of growing ram and ewes lambs. J. Anim. Sci. 70, 2746-2751.

Storry, J.E., Rook, J.A.F. and Hall, A.J., 1967. The effect of the amount and type of dietary fat on milk fat secretion in the cow. Br. J. Nutr. 21, 425-438.

Sudweeks, E.M., Ely, L.O., Mertens, D.R and Sisk, L.R., 1981. Assessing 
Effects of varying levels of dietary palm oil in concentrate rations on nutrients digestibility in Red Sokoto goats

minimum amounts and form of

Received: 19/03/13

roughages in ruminant diets: roughage

Accepted: 26/09/13

value index system. J. Anim. Sci. 53, $1406-1411$.

Sutton, J.D., Knight, R., McAllan, A.B., Smith, R.H., 1983. Digestion and synthesis in the rumen of sheep given diets supplemented with free and protected oils. Br. J. Nutr. 49, 419-432 